\title{
Cancer research in China: a Special Focus by Cell Research
}

Cell Research (2007) 17:273. doi: 10.1038/cr.2007.31; published online 16 April 2007

The year of 2007 is the $100^{\text {th }}$ anniversary of the American Association for Cancer Research (AACR), "marking a century of progress in saving lives through cancer research" (quote from the AACR website). Despite the great progress, cancer remains a top threat to human health. Continued research will be essential to winning the battle against cancer, as only through continued research would it be possible to gain better understandings, generate deeper insights, uncover new preventive and therapeutic strategies, design and test more effective treatments, and ultimately, save more lives.

Along with the rapid pace of growth of scientific research in China, the field of cancer research has also seen more and more prominent contributions by Chinese scientists. The editors of Cell Research, China's premium international journal in life sciences, have selected a number of outstanding papers on cancer research that have come out of China in the last few years to be the subject of commentaries by the authors of these articles. In this issue of Cell Research, we are pleased to feature these commentary pieces in the form of a "Special Focus", and hope that these pieces will present our readers with a quick guided tour of the field of cancer research in China.

\author{
Dangsheng Li, PhD \\ Deputy Editor-in-Chief, Cell Research \\ E-mail:dsli@sibs.ac.cn
}

